\title{
Belphégor
}

\section{Ambivalent gentleman-thieves and 'the Dutch Conan Doyle': British-based detective fiction in the Netherlands at the start of the twentieth century}

\section{Alex Rutten}

\section{OpenEdition}

\section{Journals}

Electronic version

URL: http://journals.openedition.org/belphegor/1044

DOI: $10.4000 /$ belphegor. 1044

ISSN: 1499-7185

Publisher

LPCM

\section{Electronic reference}

Alex Rutten, " Ambivalent gentleman-thieves and 'the Dutch Conan Doyle': British-based detective fiction in the Netherlands at the start of the twentieth century », Belphégor [Online], 15-2 | 2017, Online since 05 December 2017, connection on 02 May 2019. URL : http://journals.openedition.org/ belphegor/1044; DOI : 10.4000/belphegor.1044

This text was automatically generated on 2 May 2019.

\section{(c) (i) ()}

Belphégor est mis à disposition selon les termes de la Licence Creative Commons Attribution - Pas d'Utilisation Commerciale - Pas de Modification 4.0 International. 


\title{
Ambivalent gentleman-thieves and 'the Dutch Conan Doyle': British- based detective fiction in the Netherlands at the start of the twentieth century
}

\author{
Alex Rutten
}

1 In the first decades of the twentieth century, detective fiction became a force to be reckoned with. According to Chris Baldick, the rise of detective fiction was 'the most spectacular development in modern light fiction':

Formerly a marginal curiosity of the Victorian imagination, crime fiction blossomed in the Twenties and Thirties into a huge national craze. While other middlebrow-to-lowbrow genres languished under shadows of disrepute, the detective story, elevated to new distinction by the success of Arthur Conan Doyle's long cycle of Sherlock Holmes tales (1887-1927), offered a sort of intellectual challenge that made it acceptable to the highly educated, and indeed sometimes addictive. ${ }^{\mathrm{i}}$

In general, this was not only true for English literary history, but for the development of the genre in many other European countries as well. The blossoming of crime fiction was a profoundly international phenomenon. One could even connect it to a so-called 'transatlantic print culture' in which works that were originally published in the English language became a dominant factor in the commercializing and expanding print marketplace.i. In many countries, small and large, domestic literature was inspired by and/or based on Anglophone examples from popular culture, such as adventure, detective or western stories. Countless crime stories were adapted, translated and transformed within national contexts, which often led to notable changes in the way contemporaries viewed the genre as a whole.

3 This broad international perspective on the development of the genre can best be interrogated and refined by a closer, more analytical look at the specific dynamics of a 
national case. Ideally, one does not only approach popular or 'middlebrow' culture from the perspective of the new (middle-class) audiences that en masse entered the consumer market, but also from that of specific mediators that facilitated the production and international exchange of popular fiction, such as translators, agents, writers, critics, publishers and library employees. iii Thus this article will focus on the production, dissemination, critical reception and specific content of two of the most popular crime stories that were available in the Netherlands.

The Netherlands, being a small country situated between three major linguistic areas, became a quintessential import country at the start of the twentieth century. Unable to meet the public's demand with solely domestic literary production, Dutch publishers had to reach out to other countries..$^{\text {iv }}$ The statistics show that more than half of all novels published in the thirties were translations from foreign literatures. ${ }^{v}$ Although neighbouring countries such as France and especially Germany were also important import countries for the Netherlands, the interwar period showed a significant increase in the amount of popular fiction that was imported from the major and fashionable production centres in the United Kingdom (London) and the United States (New York). ${ }^{\text {vi }}$ These strong ties with and (economic and/or political) dependence on other countries, were, as we shall see, one of the reasons for many critics and intellectuals to defend national values and traditions, especially after the First World War. Typical for a 'minor' language area, the dominant presence of international literature led to 'varying degrees of awareness of a national identity' and an increasing search for an 'own' national literature. ${ }^{\text {vii }}$

In this article, I want to focus on the international aspects of detective fiction and the relationship between textual-material characteristics and the historical disapproval or appraisal of certain works by exploring the content and reception of two types of detective fiction that were very popular in the Netherlands: internationally rooted serialized pulp fiction on the one hand, and domestic novels on the other. I will provide a general description of the Lord Lister pulp series, mostly based on previous research by Dick Berents and the former Lord Lister Klub, and a more specific analysis of a Dutch detective novel: Ivans' debut, The Man from France (1917). Having set out the specific features of these texts, I will then examine how these two types of literature led to extensive discussions about the cultural values and potential dangers of detective fiction. Ultimately, this should lead to a better insight into the shifting form and status of popular literary genres.

\section{International pulp fiction: the Lord Lister series ${ }^{\text {viii }}$}

6 The German publisher Alwin Eichler played an important role in the dissemination of pulp fiction series at the start of the twentieth century. Having worked in New York for a while, he returned to Germany in 1903 with the publishing rights to the popular series Nick Carter, Wild West Weekly and Buffalo Bill. In Berlin, he obtained several more publishing rights from the Verlagshaus für Volksliteratur und Kunst. ${ }^{\text {ix }}$ This publishing company produced a lot of pulp series in the years before the First World War, such as Lord Lister, Texas Jack, Klaus Störtebecker and the unauthorized Conan Doyle rip-off Detektiv Sherlock Holmes und seine weltberühmten Abenteur.

With the publishing rights he obtained in Germany and the United States, Eichler started to build up his own enterprise by spreading translated versions of many of the 
aforementioned series all across Europe. Eichler had offices in Dresden, Paris, London and New York. He founded his own publishing company in Amsterdam, which came to be known as the Roman-, Boek- en Kunsthandel (previously A. Eichler and RomanBoekhandel), ${ }^{\mathrm{x}}$ and he also started working together with the French publisher La Nouvelle Populaire. ${ }^{x i}$ While keeping the original covers of the pulp series, he made sure their content was translated, sometimes slightly altered with regard to the target country. The original 110 German issues of the Lord Lister series, for instance, showed up in different variations in Argentina, Belgium, Brazil, Denmark, Estonia, France, Hungary, Italy, the Netherlands, Norway, Poland, Portugal, Spain, Sweden and Turkey. ${ }^{\text {ii }}$

Although the dissemination of pulp series like Lord Lister is impressive at first sight, it is often very difficult to determine the exact circulation numbers. Large print runs were no exception, since the print industry was booming at the start of the twentieth century. The Netherlands showcased a significant growth in the number of newspapers, (illustrated) magazines and pulp series that were available on the market during this period. ${ }^{\text {xii }}$ In a letter Eichler wrote to Dutch bookshops at the start of his business in 1908, he mentioned that his series had 'more than twenty thousand' readers. In the same letter, he offered different series in batches of 100 at a cost of 7 cents per copy (the retail price for one issue was 10 cents). ${ }^{\text {xiv }}$ It is likely that Eichler published at least 25.000 copies per issue. ${ }^{\mathrm{xv}}$

The issues of the Lord Lister series were published every two weeks, always 32 pages long and made from wood pulp paper. Each issue usually contained several advertisements, mainly by the publishing company itself or tobacco companies. Small cigarette boxes were cleverly hidden in the cover illustrations and advertising texts were placed more obviously between the chapters. While enjoying a new adventure of Lord Lister, a reader could encounter texts like: 'Of course, Lord Lister smokes a gentlemen's cigarette: "the Dubec-cigarette”', or: 'Lord Lister came, saw and...... lit a Dubec-cigarette'. ${ }^{\text {.vi }}$ In this case, Lord Lister's smoking habits were used to promote mass-produced cigarettes made from Turkish tobacco. There is a relationship here between the advertisements and the usual sales outlets for pulp fiction: one could buy Lord Lister in some local book shops, but mainly in kiosks, tobacco shops or train stations. Popular fiction frequently displayed a strong connection between narrative content and the places where the fiction was bought and read. These ties can be traced, for instance, in the smoking behaviour of characters or the train as a recurring location. The fact that advertisements were 'blended in' with the specific content of the crime stories and that these stories had to have the exact same length, underlines the idea that the Lord Lister series were a part of the commercial market of large-scale production.

The case of the Netherlands is exceptional when we look at the different countries for which the Lord Lister series was translated. After the translation of the original 110 German issues, Eichler continued the series by asking Dutch authors to create new adventures. After a few miscellaneous issues (issues 111-126), the journalist Felix Hageman (1877-1966) wrote a further staggering 584 stories. ${ }^{\text {xvii }}$ Hageman, who was slowly growing blind and deaf, dictated these short stories to different typists. ${ }^{\text {xviii }}$ The Lord Lister series was even continued after the Second World War, which further contributed to its success and long-lasting fame in the Netherlands and Belgium.

11 The German original as well as the Dutch prolongation are both very British-based: all the main characters are British and London functions as the main setting. ${ }^{\text {xix }}$ Lord Lister, whose criminal name is John C. Raffles, has a residence in Regent's Park and Cromwell Street. ${ }^{\mathrm{xx}}$ Just like Sherlock Holmes, Lord Lister has his own assistant, Charly Brand, who is 
also his biographer. Brand's role is similar to that of Watson, but contrary to Conan Doyle's detective stories, the Lord Lister series is not written from the perspective of the assistant, but from that of an external, third person narrator, which made it easier to make jumps in time and place within a short story. ${ }^{x i}$ Following E.W. Hornung's original Raffles (Arthur C. Raffles), and other examples, such as Maurice Leblanc's Arsène Lupin, Lord Lister was created as a so-called 'gentleman-thief' who operates on the wrong side of the law, using mostly burglary to punish evil-doers. Usually, a story revolved around Lord Lister and Charly Brand helping someone in need or encountering a specific case (in a newspaper) and taking on a criminal gang or 'bad guy'.

Unlike Hornung's original Raffles, Lord Lister is an aristocrat who possesses a lot of money and houses. In the first issue of the series, he explains why he consciously became a criminal:

A year ago, when my everyday life began to bore me, I thought about co-operating with Sherlock Holmes. After careful consideration, however, I came to the conclusion that it would be much more interesting to be the prey instead of the hunter, or, in other words: to be a criminal instead of a detective. Understand me well, Charly, I only look at this matter from a sports viewpoint. ${ }^{\text {xxi }}$

This passage suggests that Lord Lister was a kind of bored bachelor with too much money and time on his hands, who only decided to become a criminal to find a new and exciting challenge in life. The same first issue of the series, however, also contains more noble motives for his criminal activities: apparently, Lord Lister's parents were financially ruined by 'one of those prominent crooked stockbrokers from London', whose actions ultimately led to his father's suicide. Lord Lister wants to avenge his father by stealing from rich extortionists and give the money to the poor. ${ }^{\text {xxii }} \mathrm{He}$ describes himself as using the pseudonym Raffles 'to avenge the bourgeoisie on behalf of those who are in need'.

In a way, Lord Lister stands for social justice and functions as a Robin Hood figure who helps the poor by stealing from the rich. ${ }^{x x v}$ Interestingly, in the course of the series Lord Lister shows a further shift away from criminality towards detective work. Using the name Lord Aberdeen, Lord Lister starts to operate as a kind of private detective. ${ }^{\text {xxi }} \mathrm{He}$ is no longer mainly preoccupied with burglary and theft, but rather with the more puzzling task of crime-solving. The Lord Lister series thus transformed the criminal into a criminaldetective. As Dick Berents has noted:

To benefit from the success of Sherlock Holmes, the authors [of Lord Lister] described the gentleman-thief not only as a sympathetic criminal, but also as an opponent of other criminals, as an ordinary detective. By doing so, they joined the existing tradition of battles against gangs, which can be found in pulp magazines such as [Nat] Pinkerton and Nick Carter. ${ }^{\text {xxvii }}$

As a result, Lord Lister became a rather ambivalent figure. Although the series is often moralistic and Lord Lister shows that he knows how to separate good from bad, he does not always have the patience to do the right thing. Whilst he does not want to kill anybody, he does so at times. In his attempts to fight for justice, he sometimes takes the law into his own hands. ${ }^{\text {xxvii }}$ That being said, the Dutch version was in fact tamer than the original version. This already happened in the translation of the 110 German issues, which were mostly written by Kurt Matull, but still more in the new stories by Hageman that were written under the supervision of Henri Nelissen (1885-1957), the Catholic publisher who took over Eichler's business in 1922 after the latter committed suicide. Hageman and Nelissen toned the Lord Lister series down further by reducing the amount of bloodshed, murder and violence. ${ }^{\text {xxix }}$ 
Despite the Dutch versions' milder tone, Lord Lister remained an ambivalent figure throughout the series. He shows affiliation with communist ideals and strongly objects to capitalism and (financial) exploitation, but he is a wealthy aristocrat with a lot of money and possessions. He even has several treasure islands, where he keeps his stash carefully hidden. ${ }^{\mathrm{xx}}$ More essentially, he is a thief and a detective, a criminal and a benefactor. As we shall see, it is the combination of this ambivalent meaning of Lord Lister as a 'criminal hero' and the dominant presence of the international pulp series circuit on the national market of cultural goods, that led to strong concerns and fierce criticism.

\section{Domestic detective fiction: Ivans' novels}

17 Jacob van Schevichaven (1866-1935) is generally regarded as the first professional Dutch detective writer. In 1917, he published his first detective novel, The Man from France (De man uit Frankrijk), under his pseudonym Ivans. It was a success and his publisher, A.W. Bruna, asked for more manuscripts. Ivans delivered: in 1917 he published another detective novel, followed by three more in 1918. In total, Ivans wrote 33 novels in the socalled 'G.G. series' between 1917 and 1936. ${ }^{\text {xxi }}$ These series were centred around the detective Geoffrey Gill.

Bruna was one of the major Dutch publishing companies that engaged in the medium- to large-scale production of popular fiction. The continuous production of new titles was one of the key strategies of this publishing company. To a greater extent than the Roman-, Boek- en Kunsthandel, Bruna made sure that its books were advertised and distributed by the official book trading institutions. The use of better materials further differentiated Bruna from the pulp fiction circuit. For instance, by publishing Edgar Wallace's popular works in bound book editions at prices that were in the middle of the market range, Bruna branded him in such a way as to make his works fashionable and part of the mainstream print market.xxxii Similarly, Ivans novels were published in averagely priced sewn or cloth-bound versions. The novels were actually raised in price after their initial success and republished in illustrated versions. ${ }^{\text {xxxiii }}$ Bruna numbered and explicitly marketed Ivans' books as a series of adventures by Geoffrey Gill. In 1921, the first novel, The Man from France, was reprinted as a feuilleton in two newspapers ( Voorwaarts and Leeuwarder Courant), encouraging readers to start with the series and acquire the following adventures in book form. In the thirties, Bruna also published multiple novels by Ivans in one thick clothbound book, the so-called 'omnibus'. This was an innovative marketing move at the time, since this bestselling formula only became very popular with Dutch publishers and readers after the Second World War. ${ }^{\text {xxxiv }}$

Ivans' detective stories were most definitely inspired by Conan Doyle. In fact, Ivans was generally seen as 'the Dutch Conan Doyle, the man who transferred the Sherlock Holmes genre to our soil. ${ }^{\mathrm{xxxv}}$ Unsurprisingly, Ivans chose London as his main setting and a British private detective, Geoffrey Gill, as his main character. In similar fashion as Sherlock Holmes, Geoffrey Gill practises scientific 'deduction' and is accompanied by an assistant, Mr. Hendriks (Willy), a Dutch attorney who has an office in London. Taking over the already popular combination of a private detective and an assistant, and choosing Britain as the main setting, but adding the Dutchman Willy, proved to be clever moves. ${ }^{\text {xxvi }}$ This way, Ivans could benefit from the prevalent interest in and fascination for the United Kingdom, while at the same time, building an accessible bridge with the mainland, as a closer look at the aforementioned debut novel will demonstrate. 
ke the Sherlock Holmes stories, which were written from the perspective of Watson, The Man from France (1917) is told by a first person narrator, Geoffrey Gill's assistant Willy. Reminiscing over a few newspaper reports of past cases-a common trope in detective fiction-Willy begins his narration of 'a curious case from the history of criminality' (90) that started in Menton, France. ${ }^{\text {xxvii }}$ There, Willy and Geoffrey Gill encounter a murder case, but decide to return to London shortly thereafter, despite not having found the killer. On the boat to Dover they meet a certain Lord Lidderdale, who recognizes a picture of the murder victim as his former valet. Back in England, Geoffrey Gill and Willy follow the leads this new information has provided, and spend a lot of time in Stockton-Court in Durham, the luxurious residence of the Stockton family, where Willy, despite his attempts at self-control, falls in love with Lady Maud, one of the daughters. At StocktonCourt, they notice that they are being followed and conclude that the killer must have followed them all the way from France, and hence they call him 'the man from France'. After they split up, Willy starts some detective work of his own, only to find out later that he was wrong about a lot of things and that Geoffrey Gill deliberately used his naivety to trick the criminal into believing that they were clueless. Of course, Geoffrey Gill already suspected who was the real killer, namely an imposter who presented himself as Lord Lidderdale. Geoffrey Gill takes him into custody, but before the trial, the man takes his own life.

21 The fact that Willy is the narrator and that he has a Dutch background plays an important role in the (success of the) G.G. series. This assistant character allowed Dutch readers to identify with someone familiar and become a kind of participating observer, similar to Willy, in the cases that the seemingly all-knowing private detective Geoffrey Gill solves. Willy's naivety and cluelessness correspond to the situation of the curious reader, who is actively trying to solve the puzzle, but is often unable to do so until the very end of the novel. The function of Willy in the reading process can be compared with that of the Watson character in the Sherlock Holmes stories. As April Toadvine has argued, Watson functions as a middle-class man, whose (physical) capabilities and intellect are characterized by 'averageness', and who is representative of societal norms, more specifically 'a familiarly Victorian code of behaviour that privileged work ethic, respectability, and modesty. ${ }^{\text {'xxviii }}$ Watson plays an important role in Conan Doyle's stories to

allow readers to see themselves as Watson, middle-class voice and all. Readers are expected to side with Watson in his repeated marvelling in his friend's abilities, particularly because the narrator rarely allows readers all of the information until Holmes explains the solution. Conan Doyle's Watson, therefore, is no less intelligent than average readers who, try as they might to follow the clues, cannot solve the mystery and must wait for Sherlock Holmes to explain. ${ }^{\text {xxix }}$

In the same way as Watson, Willy functions as a moral compass and represents numerous societal norms. Willy is described as an honest, guileless and innocent man, whose face is an open book. His work ethic, respectability and modesty make him representative of exactly the same values as Watson, but here they are presented as typical 'Dutch' values. Ivans emphasizes Willy's Dutchness by contrasting him with the English milieu. Most noticeably, this happens in the romantic encounters between Willy and Lady Maud. See, for instance, the following description of the moment when he meets her:

I, Willem Hendriks, a simple attorney from Rotterdam, felt an unspeakable love for the daughter of one of Britain's most eminent and richest Peers. [...] then I felt the 
distance again, which separated me from Lady Maud's world. But, thankfully, as a

righteous Dutchman, I did feel high esteem for her, but no subservience. (107-108)

\section{Later, Willy says to her:}

Dear Lady Maud [...] we should understand each other correctly! I do not want to degrade myself nor my profession, that is not my nature, because the Dutchman who comes from a good family feels and knows-if he is not a fool-that he is inferior to no-one. (112)

In the end, Willy marries her, and they decide to live together in the Netherlands: 'According to my plan, I settled in Holland, because I was Dutch enough to not let myself become dependant on a rich father-in-law.' (236) Similar to Watson's stance in Conan Doyle's The Sign of Four, Willy wants to be independent of his family-in-law and not benefit from their wealth. ${ }^{\mathrm{xl}}$

Besides these societal norms, which are presented as fundamental characteristics of the (average) Dutchman, The Man from France emphasizes time and again the value of rational thinking and the repression of raw emotion. In his description of Willy's blossoming relationship with Maud, Ivans refers to the chariot allegory from Plato's dialogue Phaedrus to remind us of the need for self-control, reason and calmness. Willy is struggling with this and because he constantly reflects on his actions, he makes the reader part of his internal struggle. The novel thus addresses the question of when rationality and formal behaviour are appropriate, and when one should make room for emotions.

Geoffrey Gill plays an important role in Willy's attempt at self-control and the plea this novel makes for it. He has a Sherlock Holmes-like appreciation of 'deduction' and 'reasoning', which are 'G.G.'s cherished terms' (123), but also of 'observing', 'combining' and 'thinking' $(48,160)$. These qualities of the detective are used to make him a kind of role model for the self-control, reason and calm that Willy (and, one can imagine, the reader) tend to lack at times. The relationship between Willy and Geoffrey Gill is understood as a distinction between the 'normal man' and the scientific, clear-thinking man. Relating his first encounters with Geoffrey Gill, Willy writes:

Little did I know back then, how wilfully blind the commonly living and thinking man is, compared to the man who trained his eye on the sharpest observation and his head on the sharpest deduction. (37)

Geoffrey Gill often mocks Willy, but ultimately wants to train him to be more like a true detective, that is, to behave as a calm, rational man who never loses control over himself or a situation: 'Bravo! Self-control is a characteristic of the true man. Do not be angry, Willy! When you are calm, you are admirable.' (88) And if Willy wants to know too much too soon: 'Restrain your impatience for a few hours.' (151) Whereas Willy remains the subject of ridicule, Lady Edith, Lady Maud's sister, is repeatedly praised by Geoffrey Gill for her calmness, self-control and determination: 'Dear boy [...] you should train yourself to not always say at once what you think. Take an example from Lady Edith. She is an intelligent woman with self-control.' (78) ${ }^{x l i}$ Over the course of the story, we see that Willy begins to improve himself, as he tries not to lose himself in fantasies. (93-96) This is important, because the novel thus opposes the exact same things most critics were worried about with regard to the social and mental effects of reading (too much) popular fiction, namely the loss of self-control, especially in relation to (sexual) intimacy and violence, and the surrender to fantasy. 
use Geoffrey Gill often explicitly addresses Willy, his utterances can be read as a form of direct communication with the reader. When Geoffrey Gill is questioning an inhabitant of Stockton-Court, for instance, he addresses Willy in the following way: 'Now Lord Stockton begins to tell us something that differs from what we thought we knew. Maybe we are going to hear something else interesting!' (44) Sentences like these involve the reader in the process of solving the puzzle. In the last part of the novel, in which Geoffrey Gill extensively explains his view on the entire case, he repeatedly compares the results of his own methods with Willy's (wrong) insights in a way that makes 'Willy' easily replaceable by the reader:

'You will realise that now as well, Willy!' (178)

'You were also deceived, Willy!' (193-194)

'Did you think about that, Willy?' (199)

'Do you understand what I mean, Willy?' (200)

'You thought the bearded and masked man was Lord Lowden!' (201)

'You must remember, Willy, what happened then.' (201)

The two main characters have different functions. Whereas Willy's Dutchness, 'averageness', puzzlement, curiosity and frustration, make him an accessible and relatable character for the (Dutch) reader, Geoffrey Gill takes a leading role and functions as a 'compass' (107), someone who eventually guides the reader in the right direction. .lii $^{\text {xil }}$ In The Man from France, this guiding process is worked out very thoroughly. 75 pagesroughly one-third of the entire novel (!)-are devoted to long monologues from Geoffrey Gill, who, while smoking cigarettes, explains his view on the case from A to Z, which leads to proving Willy wrong and removing all possible doubts. As a result, he offers Willy and the reader 'the truth' (192), thus ending the criminal case with a set of satisfactory answers. While doing so, he also makes clear value judgments which help to separate 'good' from 'bad', for instance, when he calls the criminal a 'lesser being' (210) and a 'monster' (233).

Interestingly though, the novel does complicate this moral clarity in the closing pages. Geoffrey Gill talks with the criminal, whose real name is James Standerton, and upsets him by lying about his chances to blackmail the Stockton family and better his fate. After this encounter, he leaves a weapon behind, which tempts the criminal into taking his own life instead of dying on the gallows. Willy questions the detective's behaviour, but when Geoffrey Gill sees that Willy knows what he has done, he says to him: 'Do not judge too quickly and reflect on it!' (235) This is exactly what Willy does, comparing his human feelings with the strict laws he knows from his profession:

Sure, what he did is indefensible. It is even forbidden by criminal law. And yet, I did not succeed in seeing him as a morally inferior being. A man should not play Providence ; but the fact that James Standerton voluntarily took his own life [...] has something that satisfies the sense of justice. 'An eye for an eye, a tooth for a tooth!' Surely, a dangerous principle of law! But our human feelings do not always follow the principles of the law.

I am well aware that these contemplations are improper for an attorney. In God's name! (237)

The final sentence of the novel is: 'Do I, from my blessed position, have the right to judge him?' (238) By ending the novel with these explicit reflections, Ivans does not take the 'accident' for granted, but proposes a rather more complex set of moral values. His reflections reinforce the rule that one should never kill a person without just reason or cause. At the same time, though, Ivans' novel is a balancing act from beginning to end, constantly comparing the merits of rational thinking and the law on the one hand, with 
the authenticity of human emotions, doubts and intuitions on the other, as exemplified in the way Willy and Lady Maud approach each other or in the way Geoffrey Gill cares for Lady Edith. This gives depth to the story and stimulates the readers to actively reflect on the actions of the characters after they finish the story. Along with that, the novel explicitly wants to leave them with the feeling that they-just like Willy-could always fall back on the reliable compass named Geoffrey Gill, who was immediately recognizable as a good, righteous man from the very beginning. (10)

\section{Contemporary debates about detective fiction}

Detective fiction played a key role in the debates about the social and mental effects of popular fiction in the Netherlands during the first half of the twentieth century. The rise of this genre made critics feel the need to make a clear demarcation between the literary and the non-literary, and, within the latter category, between hazardous pleasureseeking and more healthy, 'useful' forms of amusement. Some critics thought Ivans was no better than the pulp series. The Dutch writer and critic Ralph Springer (1886-1942) criticized Bruna for sending a review copy of a new historical novel from Ivans to the monthly literary magazine Den Gulden Winckel:

What was Mister Bruna thinking, when he sent [...] this 'book' to a serious, critical and didactic magazine for reviewing? Is it arrogance? Or is there also something like a 'career' in the publishing world, and should this 'story of battle and adventure' be viewed as an upgrade of the 'famous' G.G. series and other titillating publications? And does this increase the position of the publisher? [...] I think 'De Prins', 'Het Leven' en 'Het Stuiversblad' are good enough to judge this kind of 'literature'. [...] We do not take Nick Carter and his like very seriously either. .liii $^{\text {xil }}$

Springer's critical reaction suggests that there were two kinds of cultural circuits, which correspond broadly to Bourdieu's theory of two 'fields' of cultural production. ${ }^{\text {xliv }}$ On the one hand, there is the ('lowbrow') subfield of large-scale production. This included the very popular illustrated magazines such as Het Leven (Life), De Prins (The Prince) and Het Stuiversblad (The Penny Magazine) and pulp series such as Nick Carter. According to Springer, Ivans' new novel belonged to that same circuit, whereas he himself and 'his' magazine, Den Gulden Winckel, belonged to a different circuit that was located nearer to the pole of small-scale production, where people devoted themselves to the serious cause of writing and reviewing 'real literature'. ${ }^{\text {xlv }}$

Using Nick Carter as a negative point of reference, as Springer did in the quote above, was definitely no exception at the start of the twentieth century. In Dutch critical discourse, pulp series, most visibly, Nick Carter and Lord Lister, quickly began to function as representatives of the lowest and also the most dangerous part of popular culture. Whether or not pulp series were appreciated by critics, they were seen as cultural goods with very low status. When the influential critic Menno ter Braak reviewed a debut novel, he stated that the second half was too conventional and that it was written in a nonliterary style, comparable to a feuilleton. According to Ter Braak, the romantic clichés went from bad to worse until they 'finally arrived at Lord Lister and Nick Carter.' ${ }^{\text {'lvi }}$

Whereas critics often had a clear opinion about serialized pulp fiction such as Nick Carter and Lord Lister, Ivans' detective novels led to more tentative and varied responses. Many critics tended to disagree with Springer. There was a relatively large group of critics who saw Ivans as a positive, 'healthy' alternative to the pulp series. Dirk Bartling (1891-1966), 
who was a director of a public library and a teacher at Utrecht University, ${ }^{\text {xlvii }}$ wrote a lengthy article in 1927 in which he tried to make a distinction between 'good and respectable light reading' and 'sensational reading', the latter being mainly associated with consumer goods. ${ }^{\text {xviii }}$ Bartling wanted to contribute to the 'general education and insights of the people' by seeking better alternatives to the most widely-read light fiction, Nick Carter, Buffalo Bill and Lord Lister, which he-like Ter Braak and others-placed on 'the lowest rung of sensational reading'. ${ }^{x l i x}$ According to Bartling, Lord Lister

is the most fluently written and most refined in the build-up of tension, but also most depraving in its worship of heroes, because the gentleman-thief, the pinnacle of sangfroid, courage and cleverness, is not completely morally sound. Yet he appears far more sympathetic than the police who are depicted as either stupid or vengeful.!

Bartling was worried about these potentially dangerous 'heroes', because they are ambivalent: they combine the good with the bad, or rather, make the bad look good. This was menacing because young people could find 'in the deeds of Lister and Nick Carter an ideal expression of manly force, resilience and courage'. ${ }^{\text {i. }}$. Referring to a personal case and the battle against 'Schundliteratur' in neighbouring Germany, Bartling saw a direct link between the popularity of these series and the growing number of crimes and suicides among boys. ${ }^{\text {lii }}$ Bartling even did some field work of his own and talked with boys from a working class background. Apparently a 16-year-old told him: 'If all burglars were like Raffles, there would be no need to catch them', and an 18-year-old boy said: 'I do not think burglary is bad, even if it is forbidden. ${ }^{\text {liii }}$

In his attempt to 'cure' the readers who were addicted to popular series, Bartling sought suitable replacements that could fulfil the needs of those who devoured the Nick Carter series week in, week out. Although he considered them definitely less harmful, he had a reserved stance towards Conan Doyle and Ivans. He questioned their attractiveness, because the detective's scientific methods (only) 'stimulate a kind of intellectual endeavour. 'liv Would people from the working class, who were only used to reading pulp series, be interested in this? For them, Bartling saw better alternatives to the pulp series in the works of Karl May and Edgar Rice Burroughs, but the latter should only be used as a stepping stone towards James Oliver Curwood. ${ }^{\text {lv }}$

In a statistical analysis for which Bartling surveyed thousands of readers, he concluded in 1937 that Ivans' G.G. series were more evenly appreciated by religious and non-religious readers alike, whereas these appreciations diverged more when readers had to pass judgment on Buffalo Bill and Nick Carter. In other words: religious readers had more problems with these series than with novels by Ivans. Furthermore, Bartling found out that the pulp series, and also Burroughs' Tarzan stories, were most appreciated by readers with a lower education, whereas Ivans was more favourably received by readers with a higher education. ${ }^{\text {lvi }}$

Throughout the interwar period, Bartling struggled to find the right books for the right people. Ivans was definitely more sound and of a better literary quality than Lord Lister, but his detective novels were too distant from the conventions of light fiction to function as a healthy alternative to the pulp series. Ideally, he wanted to replace Ivans by a new type of 'volksboek', which he described as

a kind of book that is not yet affected by the elements of 'higher' literature, which makes it accessible for the former Nick Carter reader. At the same time, it should be so well crafted and aesthetically pure that even the literary spoiled reader can enjoy it as a grand and beautiful work. .vii $^{\text {th }}$ 
The Dutch word 'volksboek' is difficult to translate. Literally it means 'book for/by the people', but it refers here to a kind of book that is national throughout, often realistic and not provocative, and that hypothetically is accessible for and relates to the entire Dutch population. Bartling valued highly the social meaning of literature and sought to make distinctions between different books and readers, helping all levels of the public to become better, healthier readers and citizens.

P.H. Ritter Jr. (1882-1962), a well-known critic, journalist, writer and radio speaker, , viii had similar interests to Bartling. Contrary to Bartling, however, Ritter was very enthusiastic about Ivans' detective novels. In his pamphlet on the social meaning of amusement literature he evaluated 'the destructive influences of the amusement novel', while comparing this kind of novel with another kind of 'amusement literature that springs from fresher sources, and-because it takes into account the healthy instincts of the people-helps to construct a national ['volksche'] culture, instead of undermining it. 'lix

Despite and partly thanks to the positive sides of characters such as Lord Lister, Ritter considered the popular pulp series as highly dangerous. Ritter summarized his complaints as follows: the series have no direct relation to or meaning for 'real' life, they offer the reader a sort of narcotic escapism, they address the great questions of life too playfully, contain hazardous erotic elements, and ultimately lead towards a mechanical, unreflective attitude to life. ${ }^{\mathrm{x}}$ Ritter wanted literature to be in touch with human life: 'To depict life, a harmonious life that can encompass lust and sorrow, elevation and tragedy, that is the goal of literature.' ${ }^{\text {lxi }}$ In an age which, according to Ritter, was becoming more and more mechanical and technocratic, this was very important. For him, a pastime should never be completely devoid of purpose or meaning: it should be elevated to 'a challenging, interesting activity'. ${ }^{\text {xii }}$ Ritter remained optimistic. He noted that the working classes already showed 'a growing development of literary taste'. lxii $^{\text {. }}$

For Ritter, the genre of detective fiction could lead to a kind of amusement literature that actually was challenging and in touch with human life. Formerly, the appeal of detective fiction was unevenly spread among the Dutch population: 'Those who enjoy the detective novel come from the lowest and the highest layers of society. The lowest enjoy them by gobbling them up naively, while the intellectual elite use the genre as a new and effective instrument for irony. "1xiv This was changing, however, as more serious writers started to write detective fiction and developed it by stripping it of some of its more 'vulgar' elements. Ivans was one of those writers. Ritter applauded him as the first author who acknowledged the dangers of detective fiction and deliberately avoided them in his own work. By doing so, Ivans had succeeded in delivering

an undoubtedly social meaning as an improver of what our people read. One can preach the literary book, but one can also bring the books that the people actually read to a higher standard. Ivans achieved this latter goal. ${ }^{\mathrm{kx}}$

Ritter was excited about what he saw as a new 'stage of development in the detective novel' and regarded Ivans as one of the key figures in this development because he was willing to provide what the public wanted, while maintaining a clear sense of leadership: Ivans does not let the public lose itself in meaningless adventures. Because of authors like Ivans the detective novel should not have to be completely discarded, but could also be reformed. ${ }^{\text {lxi }}$ This was a common pursuit in the Netherlands, where ('neutral') critics were hesitant about censorship and bans and sought rather-as Simons formulated it in 1911-'to repress the dissemination of titillating literature by replacing it with something better' 'xvii 
How did Ivans improve the genre of detective fiction? According to Ritter, the introduction of Willy accompanied Ivans' intention to make the detective-novel more Dutch. The assistant character represented the reader and made him aware of the distance between himself and the impressions of the author, thus making sure that the reader could not succumb to careless escapism. lxviii Ritter lamented the superficially international character of popular fiction which was full of English words, anglicisms and other 'foreign terms, habits and lifestyles'. The fact that Ivans tried to add a Dutch component to the popular genre of detective fiction in the form of narrator Willy, was valuable in Ritter's terms: he appreciated the way Ivans 'gave his detective stories a national character and a national sphere. ${ }^{\mid x i x}$

Although Ivans could potentially be replaced by something that was even better, Ritter saw his detective novels as a very good alternative to the pulp series. Because no national novel ('volks-roman') or culture ('volksche cultuur') existed, something was needed to fill that void. Ritter thought that the cultural field was excessively divided. On the one hand, there were intellectual writers who turned their backs on the general public, and on the other, there were mass-production factories that dominated the market with (imported) cultural goods. Ivans, who did not claim to write 'literature', could potentially break down this divide. He was a modern author who was not too proud to work on demand and positioned himself between 'high' literature and 'low' pulp fiction, combining economic motives with idealism. In an interview, Ivans distinguished himself from 'lowbrow' pulp:

In the present age, one prefers light literature. And if the public wants such a genre, than we should provide it. But preferably not in the form of Nick Carter, Lord Lister and the likes, whose adventures often follow the same recipe. ${ }^{\mathrm{kx}}$

Ivans took the reading tastes and habits of the general public seriously. He wanted to provide what the public wanted, but did not want to go too low. This meant that he had similar interests to critics like Bartling and Ritter, who were looking for a new kind of national literature and new authors who would step up as leading figures to refine, nationalize and reform popular genres.

\section{Conclusion}

Pulp fiction series such as Nick Carter and Lord Lister became very well known in the Netherlands during the interwar period. They were popular among large groups of readers and many critics gave them a place in the lower and/or negative parts of their cultural repertoires. Throughout the first half of the twentieth century, the pulp series maintained their low cultural status and were considered by many critics to be morally dangerous. Although the content of the Lord Lister series was somewhat refined when the Dutch author Felix Hageman continued the series under a new publisher, the status of this particular series did not really change. The main objection-making criminality attractive-lost little of its force, for Lord Lister remained a rather ambivalent character who continued to indulge in criminal activities.

The strong concerns critics had were probably not only based on the specific content of the pulp series, but also on their dominant public image, which was partly influenced by the (international) production and distribution circuit they were part of and by the organized 'Kampf gegen Schund und Schmutz' (fight against dirt and filth) in Germany, which did not go unnoticed in the Netherlands. ${ }^{\text {lxi }}$ Apart from these factors, the pulp series also became strongly associated with a specific kind of 'light', 'meaningless' and 
even 'addictive' form of reading and with readers with a lower education and/or a working class background, who, as Bartling showed us, also constituted the main readership for pulp fiction.

The detective novels were not so homogenously received as the pulp series. Their price and material form distinguished them from these series. The major Dutch publisher Bruna ensured that Ivans' novels were branded as fashionable products and distributed them in the official literary circuits (much to Springer's chagrin). In addition to this, the specific textual content of the novels played an important role in the image of this type of detective fiction. An issue of Lord Lister was only 32 pages long, which offered little space for extensive reflection or explanation. Novels, however, had more than enough space for this, and Ivans made full use of it. This meant that even where legal rules were challenged, for instance when Geoffrey Gill perfoms an act that is, strictly speaking, illegal at the end of The Man from France (which could hypothetically lead to complaints similar to those directed at the Lord Lister series), Ivans could use the narrative scope of his novel to counter this with a discourse that defended moral and societal norms. Thus he could contextualise a particular case of what, in the novel's terms, is justified transgression, within an overall tone of moral soundness and social conformity

What the pulp series and the detective novels had in common was an endless fascination for England. Apparently, the public could not get enough of these stories centred around London, gentlemen-thieves, aristocrats and private detectives. Ivans, however, explicitly added Dutch elements to his British-based detective fiction. This not only led to the greater success of the G.G. series, but also to better appraisals by critics. The content of Ivans' novels and his motives were in line with the interests of the many critics who were concerned about the arousing and titillating effects that light reading could have on the masses and who sought healthier, mentally more challenging and domestic alternatives.

Gaining a better insight into the content and reception of popular genres provides an excellent starting point for the study of shifts in cultural hierarchies and the national and international developments that were entangled within these shifts. This article has shown how two kinds of detective fiction were creatively adapted and transformed by writers such as Hageman and Ivans and differently evaluated by several critics who mostly approached reading and literature as a social praxis. There seems to be a strong connection between the textual characteristics of the domestic detective novels on the one hand, and a particular kind of interwar criticism on the other, a connection that could be studied further as part of the interrelated activities that created a so-called 'middlebrow' culture during the interwar years. Popular critics such as Ritter were not the only ones who tried to bridge the gap between 'high' and 'low' and proclaimed themselves to be mediators between contemporary literature and the common reader; Ivans also saw himself as a mediator who could provide an alternative to all those international pulp series, and joined the critics' quest for a new national literature. ${ }^{\text {Ixxii }}$ It was not only Ivans' protagonist Willy who had to call upon his Dutchness to maintain his self-respect in an intimidatingly English milieu. In a way, the domestic detective novel had to do exactly the same in a cultural market in danger of being overwhelmed by imported popular fiction. 


\section{BIBLIOGRAPHY}

Andringa, Els, and Sophie Levie, 'Transfer and Integration: Foreign Literature in National Contexts', in Arcadia 44, 2 (2009), 229-236.

Anonymus, Lord Lister genaamd Raffles: De groote onbekende no. 1 (Amsterdam: Roman-boekhandel, 1912).

Anonymus, 'Een interview met mr. van Schevichaven', in Den Gulden Winckel 25 (1926), 186-187.

Anonymus, Lord Lister genaamd Raffles: De groote onbekende no. 874, 'Het monster-vliegtuig'

(Amsterdam: Roman-, Boek- en Kunsthandel, 1930)

Ardis, Ann, and Patrick Collier (eds.), Transatlantic Print Culture, 1880-1940: Emerging Media, Emerging Modernism (Basingstoke: Palgrave Macmillan, 2008).

Baldick, Chris, The Modern Movement: The Oxford English Literary History: Volume 10. 1910-1940 (Oxford: Oxford University Press 2004).

Bartling, D., 'Sensatiegenot: Een sociaal-psychologische schets', in Bibliotheekleven 12 (1927), 1-11, 21-24, 37-39, 51-57, 68-74, 83-99, 114-132.

Bartling, D., 'De romanlezer: Proeve van een onderzoek inzake de motieven der waardeering van den roman bij Nederlandsche lezers', in De Gids 101 (1937), 290-310.

Berents, Dick, Pulp: Gentleman-inbrekers in de triviaalliteratuur (Soesterberg: Aspekt 2014).

Bourdieu, Pierre, 'The market of symbolic goods', in: Pierre Bourdieu, The Field of Cultural production (Cambridge: Polity Press 1993), 112-144.

De Leeuw, Kees, Een nuchtere romanticus: leven en werk van Ivans: mr. Jakob van Schevichhaven, 1866-1935 (Soesterberg: Aspekt, 2004).

Docter, Cor, Grossiers in Moord \& Doodslag: Veelschrijvers in Nederland en Vlaanderen (Amsterdam: Meulenhoff, 1997).

Dunnett, Jane, 'Supergiallo: how Mondadori turned crime into a brand', in the italianist 30 (2010), 63-80.

Dunnett, Jane, 'Crime and the Critics: On the Appraisal of Detective Novels in 1930s Italy', in The Modern Language Review 106, 3 (July 2011), 745-764.

Heilbron, Johan, and Gisèle Sapiro, 'Outline for a sociology of translation: Current issues and future prospects', in Michaela Wolf and Alexandra Fukari (eds.), Constructing a Sociolgy of Translation (John Benjamins, 2007), 93-107.

Ivans, De Man uit Frankrijk: Uit het leven van Geoffrey Gill. (Utrecht: A.W. Bruna \& Zoon, fourth edition, [1931]).

Major, Patrick, “'Trash and Smut”: Germany's Culture Wars against Pulp Fiction', in KarlChristian Führer and Corey Ross (eds.), Mass Media, Culture and Society in Twentieth-Century Germany (Basingstoke: Palgrave Macmillan 2006), 234-250.

Marinus, Anne, and Antoon Kunst, Honderd jaar Nederlandstalige pulpbladen (Hasselt: Lord Listerklub Nederland 2009). 
Mosheuvel, L. 'Dirk Bartling', in Jaarboek van de Maatschappij der Nederlandsche Letterkunde te Leiden, 1970-1971 (Leiden: E.J. Brill, 1972), 29-34.

Ritter Jr., Dr. P.H., De sociale beteekenis van de amusements-literatuur (Zeist: G.J.A. Ruys, 1926).

Rutten, Alex, 'Goedkoop, Groot, Geillustreerd: Literatuurkritiek en publieksbemiddeling in Morks' Magazijn (1910-1942) en “Zij”: Maandblad voor de vrouw (1916-1942)', in Nederlandse Letterkunde 18, 3 (December 2013), 161-178.

Sanders, Mathijs, 'Het buitenland bekeken', in H. van den Braber and J. Gielkens (eds.), In 1934. Nederlandse cultuur in internationale context (Amsterdam: Querido, 2010), 301-312.

Sanders, Mathijs, and Alex Rutten, 'Who framed Edgar Wallace? British Popular Fiction and Middlebrow Criticism in the Netherlands', in Kate Macdonald and Christoph Singer (eds.), Transitions in Middlebrow Writing, 1880-1930 (Basingstoke: Palgrave Macmillan, 2015), 223-241.

[Simons, Leo], 'Bestrijding der Prikkellectuur', in De Ploeg 3, 7 (January 1911), 232-247.

Springer, Ralph, 'Het verre koninkrijk. Een verhaal van strijd en avontuur, door Ivans', in Den Gulden Winckel 19 (1920), 43.

Ter Braak, Menno, 'Volk en cultuur', in Menno ter Braak, Verzameld werk. Deel 7 (Amsterdam: Van Oorschot 1951), 171-176.

Toadvine, April, ‘The Watson Effect: Civilizing the Sociopath', in: Lynnette Porter (ed.), Sherlock Holmes for the 21st Century: Essays on New Adaptations (Jefferson, North Carolina / London: McFarland \& Company 2012), 48-64.

Van Boven, Erica. Bestsellers in Nederland 1900-2015 (Antwerpen / Apeldoorn: Garant 2015).

Van der Weel, Adriaan, 'Scouting for Popular Fiction Between the World Wars', in M. Delft, F. de Glas and J. Salman (eds.), New Perspectives in Book History. Contributions from the Low Countries (Zutphen: Walburg Pers 2006), 203-218.

Van Gerwen, J.J.A., 'Lord Lister, alias Raffles, de grote onbekende', in Klubblad Lord Lister Klub no. 23 (May 1989), 4-7.

Van Gerwen, Jan, ‘Kritische kijk op Lord Listers', in Lord Lister Klubblad no. 42 (July 1992), 20-22.

Van Gerwen, Jan, 'Raffles als automaat', in Lord Lister Klubblad no. 100 (April 2006), 61-62.

Van Herpen, Jan. J., Met bestendig jeukende pen: Documentair Klein Memoriaal over leven en werk van dr. P.H. Ritter Jr. (1882-1962) (Nijmegen: Flanor, 2009).

\section{ENDNOTES}

i. Baldick 2004, 273.

ii. Ardis and Collier 2008.

iii. Heilbron and Sapiro 2007.

iv. Sanders and Rutten 2015, 225-227.

v. Sanders 2010.

vi. Van der Weel 2006, 208.

vii. Andringa and Levie 2009, 233.

viii. I would like to thank Dick Berents for sharing with me his knowledge and collection of the Lord Lister series.

ix. Berents 2014, 45-48. 
x. The Dutch name 'Roman-, Boek- en Kunsthandel' can refer to a store which sells novels, books and art or, in a more general sense, to the trade ('handel') in these things.

xi. Docter 1997, 43.

xii. Berents 2014, 58-60; Docter 1997, 56-57; Van Gerwen 1989.

xiii. Rutten 2013; Marinus and Kunst 2009.

xiv. Letter Eichler, September 1908. Cited from Klubblad Lord Lister Klub no. 3 (April 1985), 5. My translation.

xv. Van Gerwen 2006. See also Klubblad Lord Lister Klub no. 3 (April 1985), 4.

xvi. Anonymus 1930, 10, 18. My translations.

xvii. Berents 2014, 74.

xviii. On Hageman, see Berents 2014, 71-78

xix. Berents 2014, 13 .

xx. Berents 2014, 65, 123. The first issue of the series already contained multiple references to Sherlock Holmes. See Anonymus 1912. See also Berents 2014, 27, 66.

xxi. Berents 2014, 28, 37, 79, 97.

xxii. Anonymus 1912, 13. All translations are mine.

xxiii. Anonymus 1912, 26. See also Berents 2014, 90.

xxiv. Anonymus 1912, 26.

xxv. Berents 2014, 14-15, 64 .

xxvi. From Hageman's 584 issues, 30 contain detective stories (5\%) and 210 battles against criminal gangs (36\%). Berents 2014, 132, 138.

xxvii. Berents 2014, 223. My translation.

xxviii. Berents 2014, 11, 109, 128, 157.

xxix. Berents 2014, 67-68, 157. Van Gerwen 1989 and 1992.

xxx. Berents 2014, 108, 123.

xxxi. De Leeuw 2004, 269-272.

xxxii. Sanders and Rutten 2015. See also Dunnett 2010 and 2011 for similar branding processes in Italy.

xxxiii. See Brinkman's Catalogus (1916-1920), 315.

xxxiv. Van Boven 2015, 117-119. De Leeuw 2004, 272.

xxxv. Leeuwarder courant, 18 November 1921.

xxxvi. Many people thought that a Dutch private detective would not be credible. Other series with Dutch detectives were not very successful. De Leeuw 2004, 208-209.

xxxvii. The page numbers refer to the fourth edition, Ivans 1931, which is available online via www.delpher.nl. All translations are mine.

xxxviii. Toadvine 2012, 53.

xxxix. Toadvine 2012, 52-53.

xl. Toadvine 2012, 53-54.

xli. On (Geoffrey Gill's appraisal of) Edith, see also Ivans 1931, 109, 173, 204, 206.

xlii. See also Ivans 1931, 36, 109, 125, 159.

xliii. Springer 1920, 43. My translation.

xliv. See for instance Bourdieu 1993.

xlv. Springer 1920, 43.

xlvi. Ter Braak 1951, 174. My translation.

xlvii. Mosheuvel 1972.

xlviii. Bartling 1927, 2. All translations are mine.

xlix. Bartling 1927, 93.

1. Bartling 1927, 115.

li. Bartling 1927, 91.

lii. Bartling 1927, 91. 
liii. Bartling 1927, 117.

liv. Bartling 1927, 121.

lv. Bartling 1927, 118-119.

lvi. Bartling 1937, 308.

lvii. Bartling 1927, 122.

lviii. On Ritter, see Van Herpen 2009.

lix. Ritter 1926, 37. All translations are mine.

lx. Ritter 1926, 34-35, passim.

lxi. Ritter 1926, 65.

lxii. Ritter 1926, 36.

lxiii. Ritter 1926, 38.

lxiv. Ritter 1926, 38.

lxv. Ritter 1926, 41-42.

lxvi. Ritter 1926, 39, 42-43.

lxvii. Simons 1911, 232. My translation. On Simons, see Erica van Boven's article in this issue of Belphégor.

lxviii. Ritter 1926, 39-41.

lxix. Ritter 1926, 25-26, 43.

lxx. Anonymus 1926, 187. My translation.

lxxi. See for instance Sanders and Rutten 2015; Major 2006.

lxxii. Sanders and Rutten 2015, 225.

\section{ABSTRACTS}

This article explores the content and reception of two kinds of British-based detective fiction that were widely-read in the Netherlands at the start of the twentieth century: serialized international pulp fiction (the Lord Lister series) on the one hand, and domestic novels (from the Dutch writer Ivans) on the other. The Lord Lister series was generally regarded as the lowest part of popular culture and as very dangerous because the ambivalent 'gentleman-thief' Lord Lister, the criminal hero of the series, could influence young people to confuse right and wrong. The novels by the popular Dutch writer Ivans, 'the Dutch Conan Doyle', were received more positively. Ivans, who explicitly positioned himself between 'low' and 'high' culture, countered the ongoing complaints against popular fiction by offering novels that defended moral and societal norms and strived towards a harmonious balance between human emotions and rational thinking. His attempt to provide a 'healthier' and national kind of detective fiction was in line with the wishes of critics who functioned as mediators between contemporary literature and the common reader and were concerned with the social and mental effects of reading too much (imported) popular fiction.

\section{INDEX}

Mots-clés: middlebrow, detective fiction, pulp, the Netherlands 


\section{AUTHOR}

\section{ALEX RUTTEN}

Alex Rutten is a PhD student in Literary and Cultural Studies at the Open University of the Netherlands. In his research, he focuses mainly on popular culture, literary criticism and cultural mediation during the interwar period. Currently, he is finishing his dissertation on the Dutch (radio) critic, journalist and writer Dr. P.H. Ritter Jr. 